Environment Conservation Journal 14(3)151-159, 2013

ISSN 0972-3099 (Print) 2278-5124 (Online)

Abstracted and Indexed

\title{
Avifauna of CCS university campus, Meerut (U.P.)
}

\author{
Nisha Rana, Rohit K. Pandey and Sanjay K. Bhardwaj凶
}

Received: 21.07.2013

Revised: 7.09.2013

Accepted: 24.10.2013

\begin{abstract}
The present systematic field study was conducted on the investigation of avifauna (bird species) in the specific sites (local habitat) of CCS University Campus, Meerut for five months from February to June 2012 (Spring-Summer). Observations were recorded in monthly and different time of the day (morning, mid-day and evening). Various variables like family name, habitat preference and characteristic features (identifying features) were noted during the survey. A total of 42 species, belonging to 12 orders, 26 families and 36 genera, were recorded. The most of the bird's species are frequently visitor and also the most of species used more than one habitat and the highest number of species, $38(90.47 \%)$, was observed on the trees, whereas the lowest number of species, $4(9.53 \%)$, was found around the ponds.
\end{abstract}

Keywords: Avifauna, bird diversity, habitat, survey sites, species

\section{Introduction}

India has the large biodiversity regions contains agricultural fields, deserts, grassland and forest as well as the highest ranges of mountains in the world. The seasonal environmental conditions and variation in rainfall at different regions are responsible for having different types of ecosystems, which supports to the varied avifauna. The thick evergreen vegetation supports to specific adaptation of bird species. The grasslands and agriculture fields from plane region supports the indigenous local inhibiting bird's species. In world, $12 \%$ animal biodiversity covered by Indian avian species and in Indian sub-continental region supports more than 1219 species of birds contribute total animal biodiversity of world (Grimmett et al., 1998; Kumar et al., 2000). This subcontinent rich in avian fauna (or avifauna) also boasts of 48 bird families out of the total 75 families in the world (Grimmett et al., 1998). The geographical ramifications of Southeast Asia, the tangled patterns of mountain chains, river drainage systems and a long period of stable climate seem to have been ideal for the evolution of a wide array of species of birds (Ali and Ripley, 1987). A bird species highly adapted to a specific plant species, community or structure, is also able to

\section{Author's Address}

Department of Zoology, Ch. Charan Singh University, Meerut

Email: drskumar7@yahoo.com describe the vegetation conditions and consequently the ecosystem situations (Uliczka and Angelstam, 2000; Jansen and Robertson, 2001).The term of Avifauna is refers to Bird Fauna or Avifaunal. Avifauna is owned and operated by the Swedish Ornithological Society. Since 1995, hundreds of field trips have been carried out, mainly in Europe but also world wide-including Antarctica. Approximately 30 bird watching expeditions are organized every year. According to Brush and Clark (1983), in almost all areas of scientific inquiry, whether theoretical or applied, proper identification of the organisms or species under study is essential. The increasing refinement and quantification of biological investigation requires comparative exactness in the identification of organisms used in both basic and applied research. By now the number of bird species and for that matter, the number and distribution of geographic races have been all but not completely determined (Steresemann, 1975).The bird life of Uttar Pradesh is rich and varied. Nearly 500 species are found, including some extremely rare ones. Among the critically endangered species, oriental white-backed vulture (Gyps bengalensis), long-billed vulture (Gyps indicus) and slender-billed vulture (Gyps tenuirostris) are found in this State. Bird Life International (2001) has listed ten endangered species; the bengal florican, the white-headed duck 
(Oxyura leucocephala) and lesser florican (Sypheotides indica) are occasionally seen and the greater adjutant, (Leptoptilos dubius) has not been recorded recently (Rahmani et al., 1990). In Uttar Pradesh, 20 out of 57 vulnerable species have been recorded. BirdLife International (2001) has listed 52 near threatened bird species from India, 14 of which occur in Uttar Pradesh.The data of bird survey are used to assess whether a piece of land should receive legal protection from governments and their agencies; such designations are important to conservation because they are intended to constrain potentially damaging activities. Information on population sizes of individual species can also be used to set priorities, allowing conservation effort to be focused on those species most in need of attention. In general, smaller population size is associated with greater risk of extinction locally, regionally or globally. Such information is collected by undertaking surveys over varying geographical areas. Birds in many ways are ideal part for biological investigations (Stresemann, 1975). In this short term investigation we report the strength of avifauna at Chaudhary Charan Singh University Campus, Meerut (UP).

\section{Material and Methods}

Study area: We identified the avian fauna in four sites of CCSU Campus, Meerut [District - Meerut $\left.\left(29^{\circ} 01^{`} \mathrm{~N} ; 7^{\circ} 45^{`} \mathrm{E}\right), \mathrm{UP}\right]$ during the period of four months (February, 2012 to June, 2012) and covering the following seasons; late winter, spring and early summer. Four sites were selected for survey in CCSU Campus, Meerut and the selections of sites were based on bird's habitat. These sites included forest, grassland, agriculture field, residential area, shrubby areas and pond. These sites are marked as Site -1 , Site - 2, Site - 3 and Site - 4, shown in Figure 1 (University map).

Vegetation of study sites: The diversity of main habitat type is shown on Figure 2. These land cover types can be classified in the major categories: residential, forest, agriculture field, pond and shrubby areas. Types of sites were: Site 1 (Shrubby and grassland areas of botany department):, Site - 2 (Pond area of new girls hostel), Site - 3 (Forest area of Freedom Fighter Matadeen Valmiki Tapovan) and Site - 4 (Mixed habitat; forest, grassland and agriculture field of Sir
Chhotu Ram Institute of Engineering and Technology).

Observation methodology: The suitable habitat patches identified for each species were mapped and those with species and without species records were selected for field survey. By using local maps the representative locations were found. The periodic observation was done at three times in a day: morning (before and after the sunrise), mid of the day and evening (before the sunset). Mainly eye observations were made to watch the birds. Often a binocular (Olympus: 8-16X40 Zoom DPS I, UV protective) was used to locate the bird at a distance and to observe them more clearly. A digital camera [Sony Cyber-Shot (DSC-HX 100V; 16.2 mega pixels with 30x optical zoom; full HD movie)] was used to take photographs of the birds.

Species identification: The identification of birds was done using field guides such as "A pictorial guide to the birds of the Indian subcontinent" (Ali and Ripley, 1989), "Birds of Northern India" (Grimmett and Inskipp, 2003). The identification of species was also done with the help of standard literature of "Collins Handguide to the Birds of Indian sub-continent." (Woodcock, 1980) and "A pocket guide to the birds of the Indian subcontinent" (Grimmet et al., 1999).

The following three characteristics were applied to identify the bird species.

External morphometry: Colour, shape, size, beak, leg and tail of the birds were the most important features for the identification of bird's species.

Song and calls: Identification of bird's species was also made on the basis of songs or/and calls of the birds.

Habitats: The species were also identified by observing the habitats of the birds: 1. open area, 2 . agricultural land, 3. Human habitations, 4. tree, 5. pond, 8. other water bodies.

\section{Results and Discussion}

Observations were recorded in respect of different parameters. Various variables like family name, habitat preference and characteristic features (identifying features) were noted during the survey period. During the present investigation, a total of 42 species of birds belonging to 36 genera and 26 different families (12 orders) were recorded from all four sites. The figures of all birds species is shown on Plate I to III. 


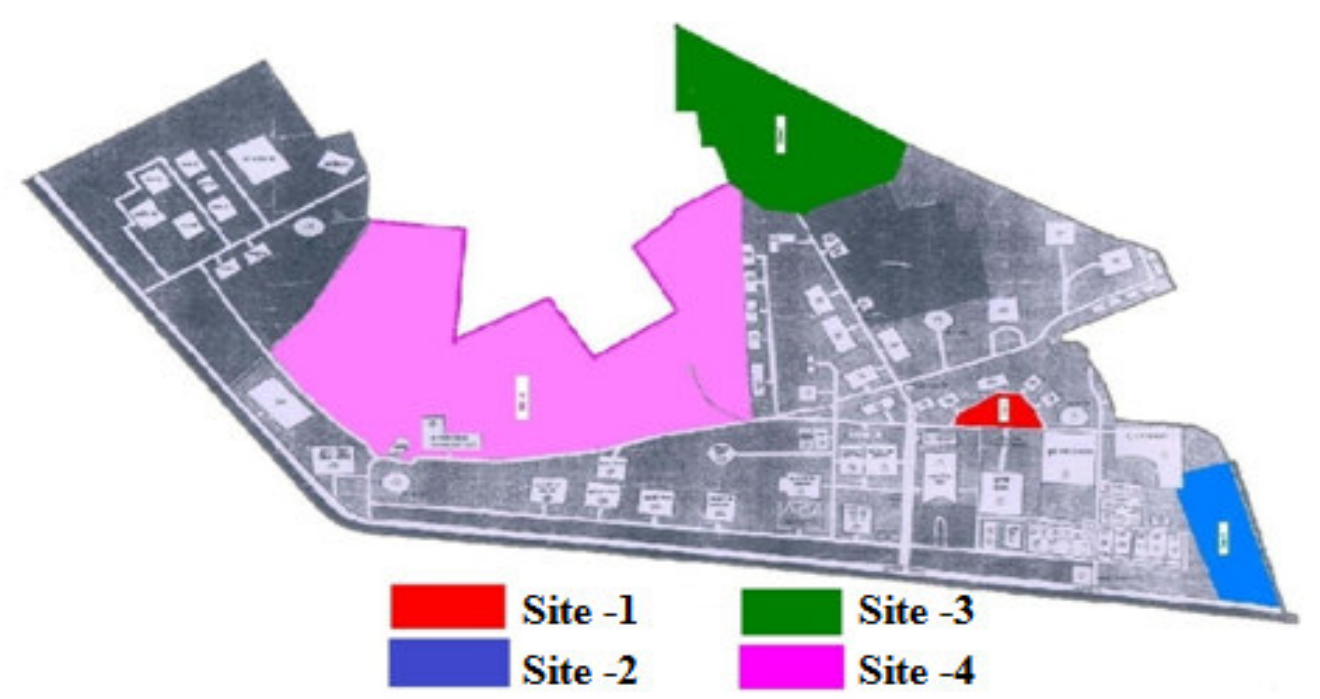

Figure 1 - Chaudhary Charan Singh University Map

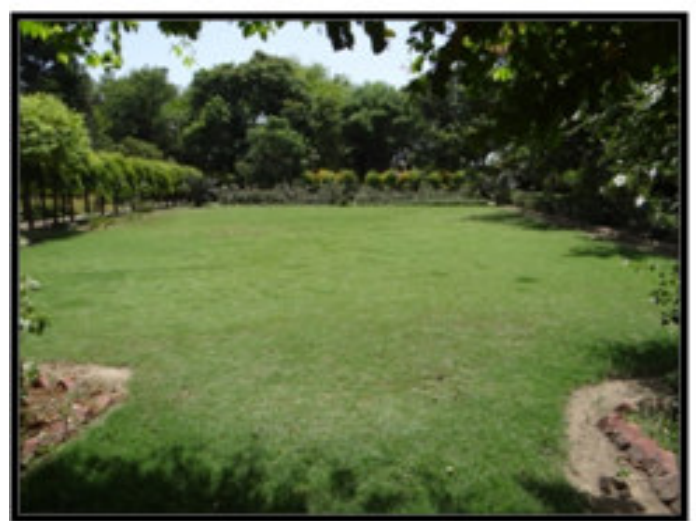

Site-1

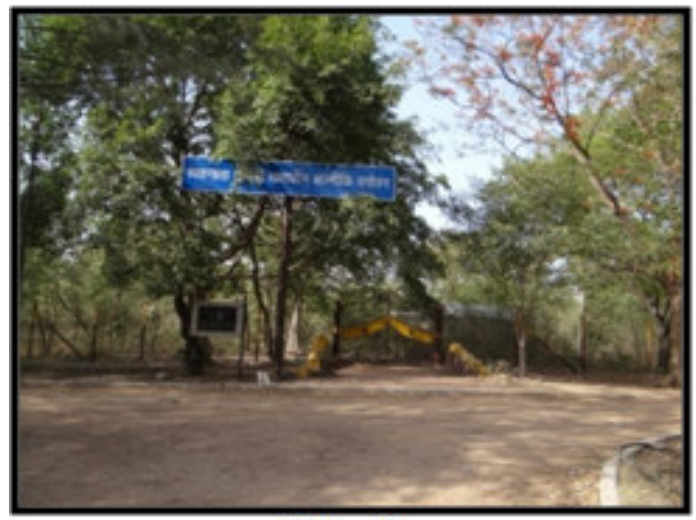

Site-3

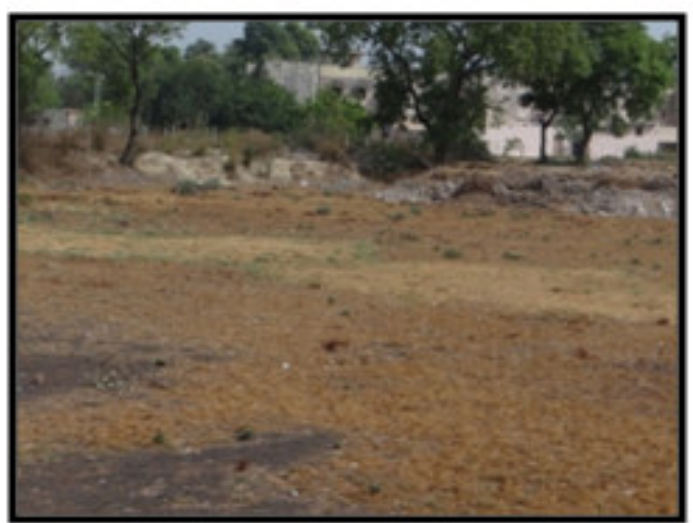

Site-2

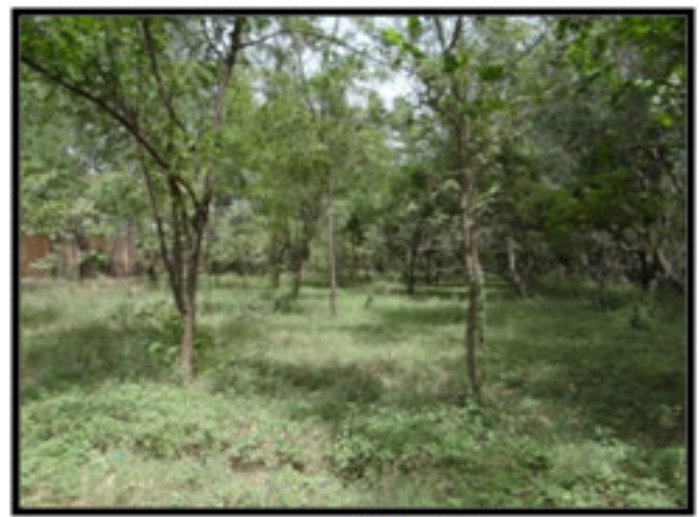

Site-4

Figure 2 - Four sites of Chaudhary Charan Singh University Campus 
Plate -I

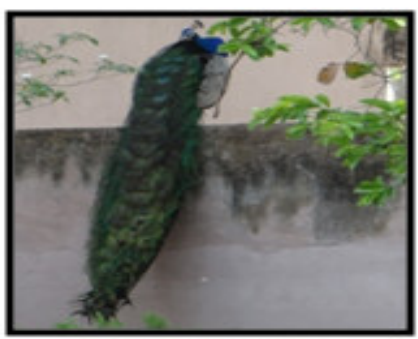

Pavo cristatus

Family-Phasianidae

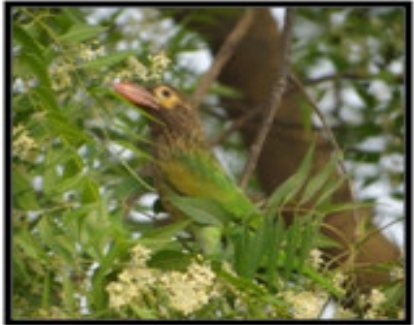

Megalaima zeylanica

Family-Megalaimidae

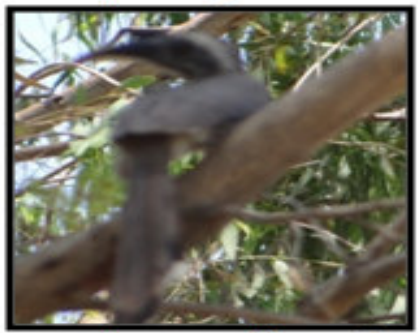

Ocyceros birostris

Family- Burcerotidae

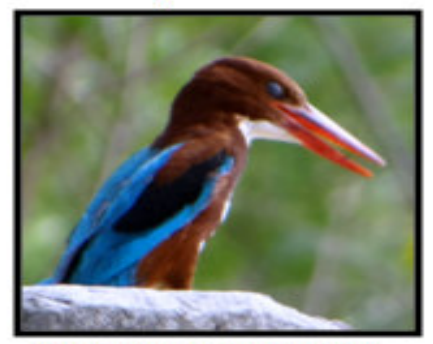

Halcyon smyrnensis

Family-Halcyonidae

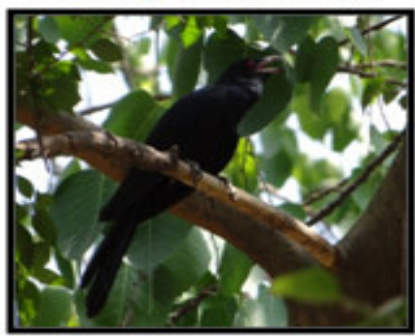

Eudynamys scolopacea Family-Cuculidae

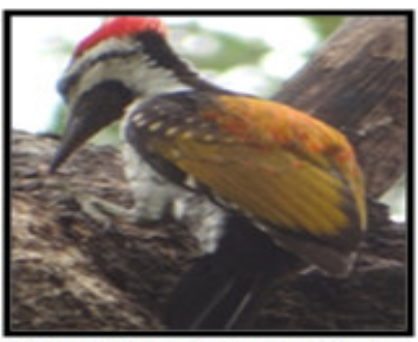

Dinopium benghalense

Family-Picidae

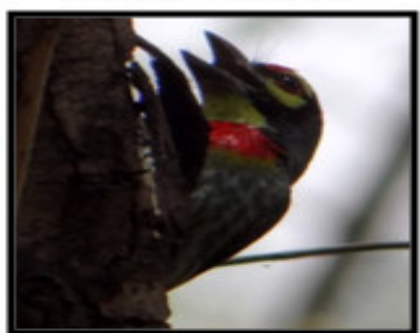

Megalaima haemacephala Family-Megalaimidae

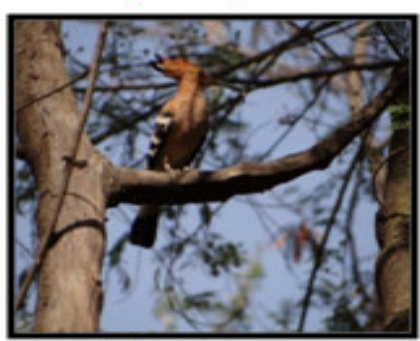

Upupa epops

Family-Upupidae

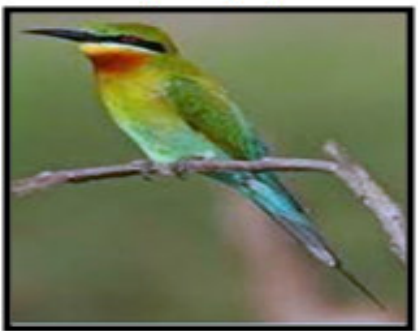

Merops philippinus

Family-Meropidae

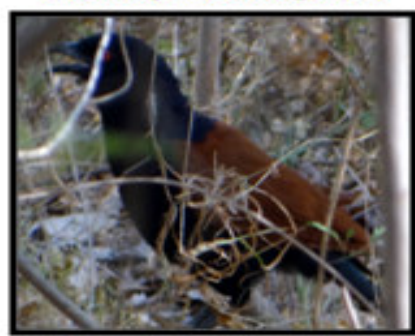

Centropus sinensis

Family-Cuculidae

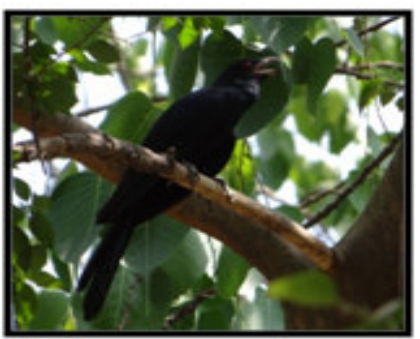

Eudynamys scolopacea Family-Cuculidae

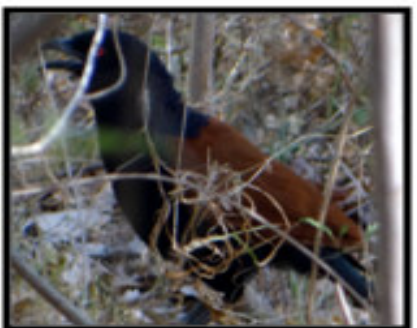

Centropus sinensis Family- Cuculidae

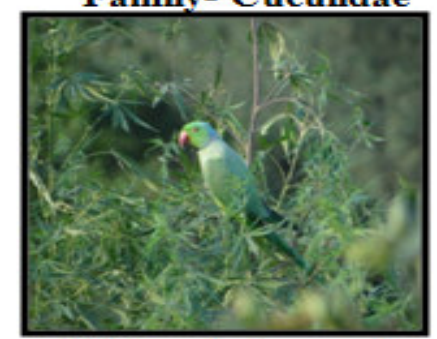

Psittacula krameri Family-Psittaculidae

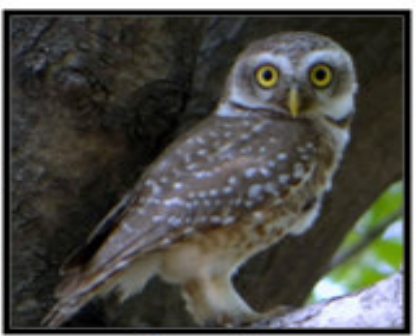

Athene brama

Family-Strigidae

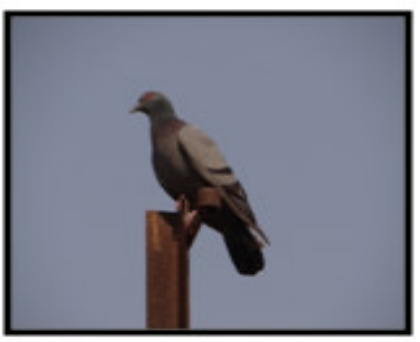

Columba livia

Family-Columbidae

154

Environment Conservation Journal 


\section{Plate -II}

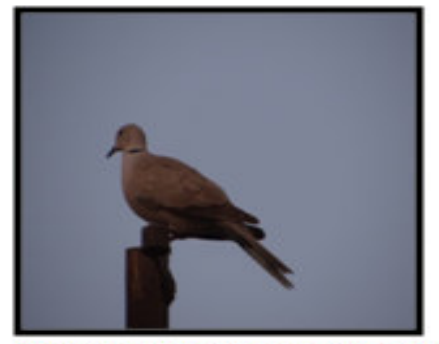

Streptopelia senegalensis Family-Columbidae

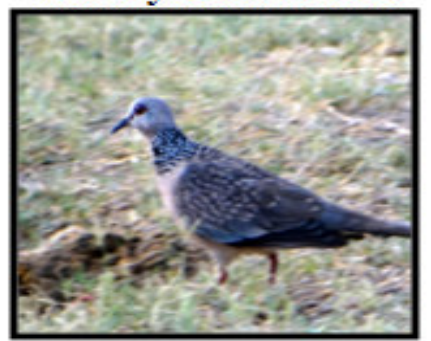

Streptopelia chinensis

Family-Columbidae

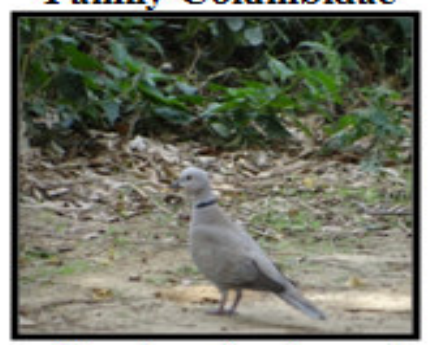

Streptopelia decaocto

Family-Columbidae

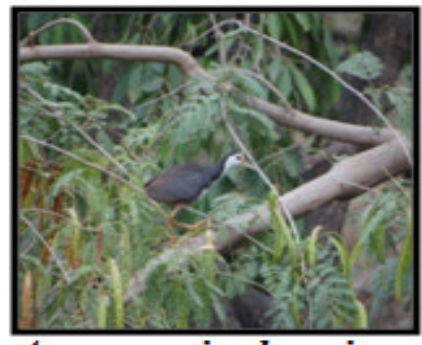

Amaurornis phoenicurus

Family- Rallidae

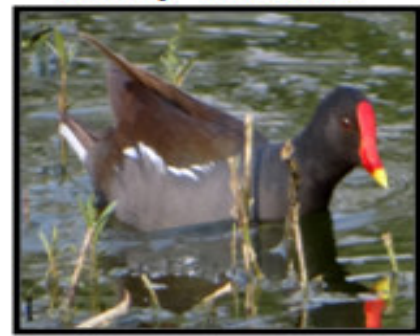

Gallinula chloropus

Family- Rallidae
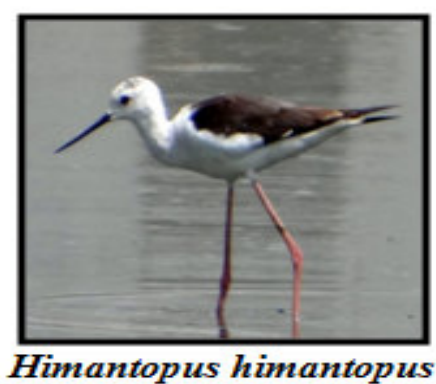

Family- Recurvirostridae

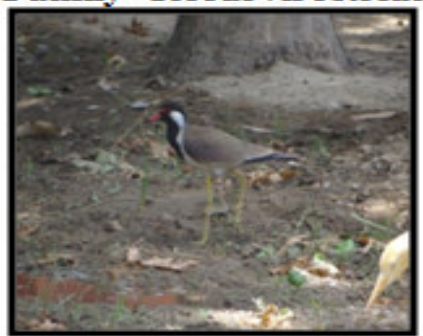

Vanellus indicus

Family-Charadriidae

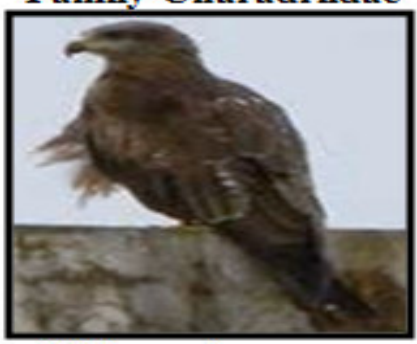

Milvus migrans

Family-Accipitridae

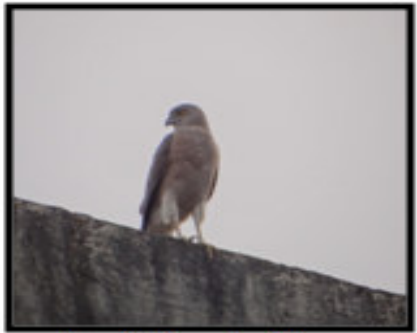

Accipiter badius

Family-Accipitridae

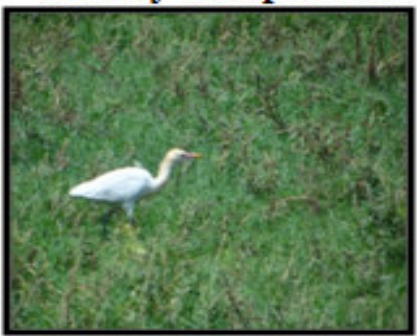

Bubulcus ibis

Family-Ardeidae

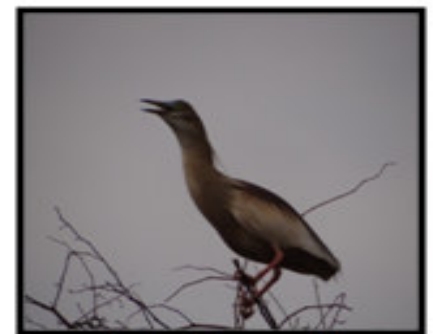

Ardeola grayï

Family-Ardeidae

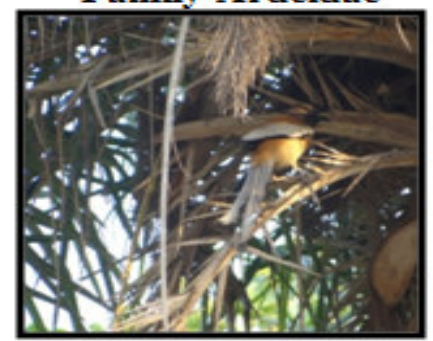

Dendrocitta vagabunda

Family-Corvidae

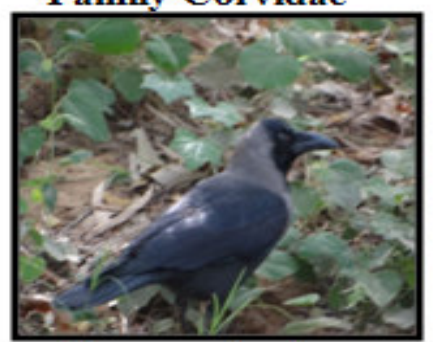

Corvus splendens

Family-Corvidae

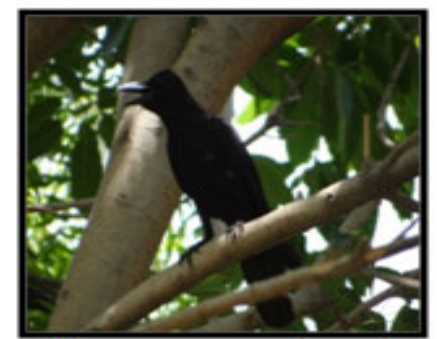

Corvus macrorhynchos Family-Corvidae

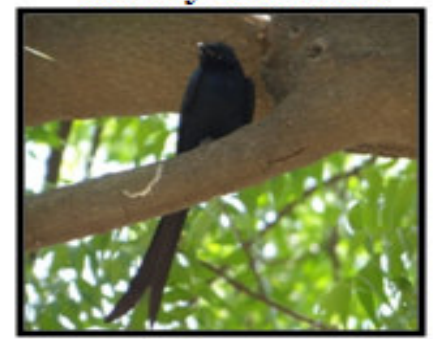

Dicrurus macrocercus

Family-Dicruridae 


\section{Plate-III}

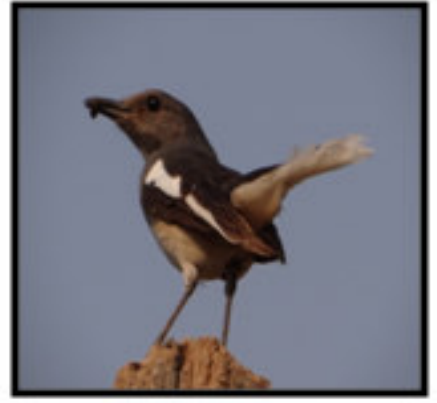

Copsychus saularis Family-Muscicapidae

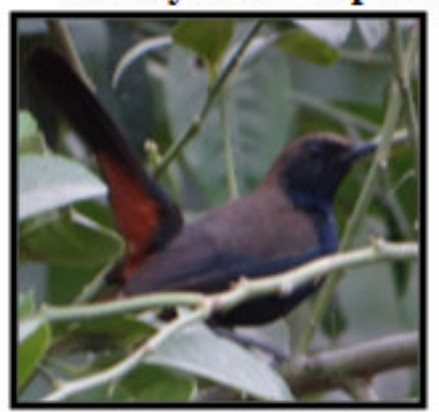

Saxicoloides fulicatus

Family-Muscicapidae

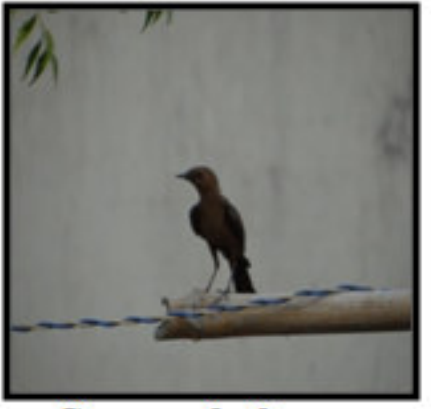

Cercomela fusca

Family-Muscicapidae

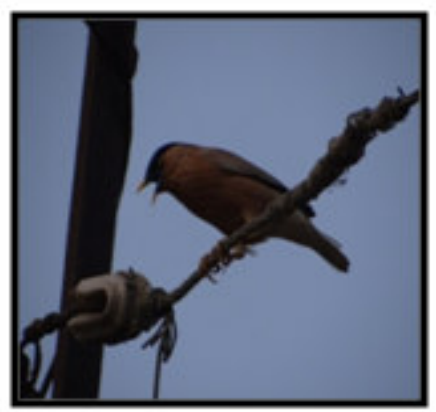

Sturnus pagodarum

Family-Sturnidae

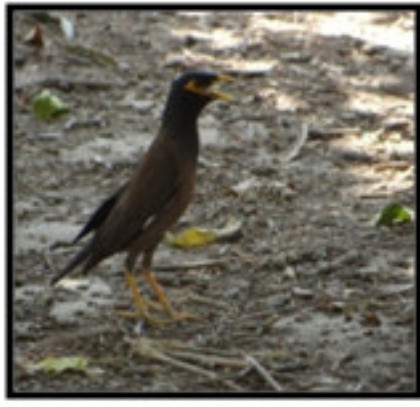

Acridotheres tristis

Family-Sturnidae

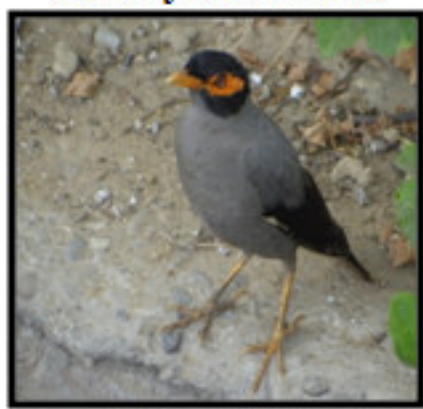

Acridotheres ginginianus

Family-Sturnidae

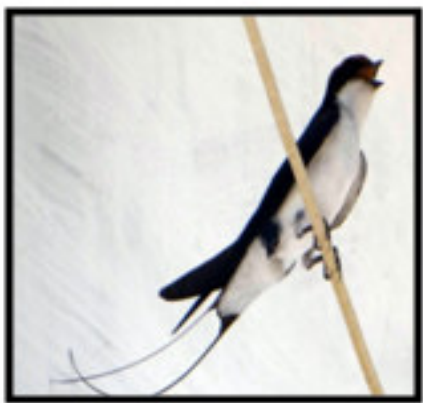

Hirundo smithï

Family- Hirundinidae

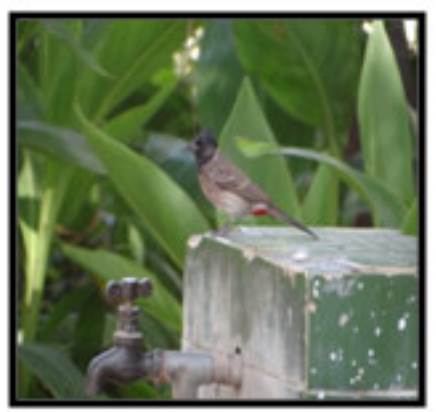

Pycnonotus cafer

Family-Pycnonotidae

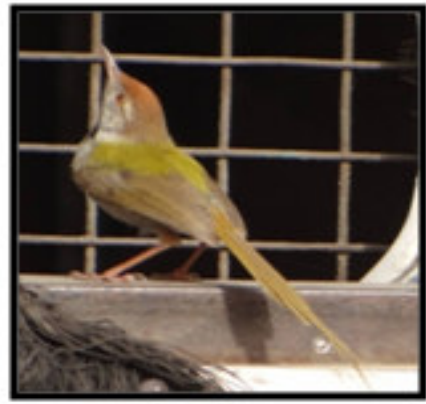

Orthotomus sutorius

Family-Sylviidae

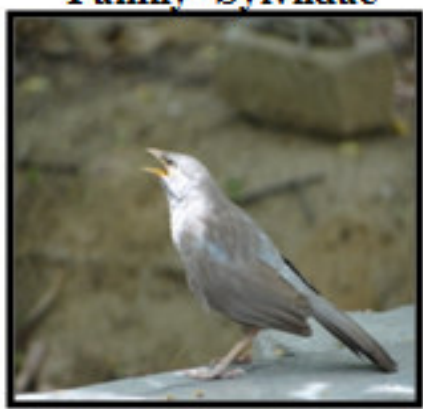

Turdoides striatus

Family- Sylviidae

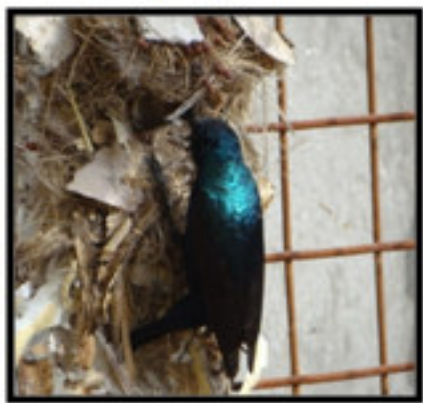

Nectarinia asiatica

Family-Nectariniidae

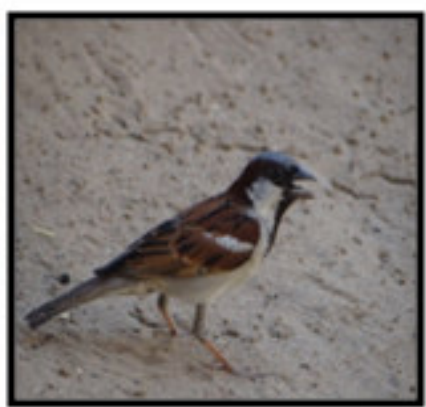

Passer domesticus

Family-Passeridae 
Mostly birds prefer mixed habitat and their feeding depend upon availability of them. The environmental factor such as temperature, appropriate conditions (i.e., availability of food, competition) also play an important role in selection of habitat. The given 42 species were identified during survey.This investigation revealed that the total four sites covered 42 species, 36 genus, 26 different families and 12 different orders of bird spp. The members of family columbideae, sturnideae, corvideae and musicapideae were widely distributed in all four sites. Columba livia, Vanellus indicus, Milvus migrans, Corvus splendens, Dicrurus macrocercus, Acridotheres tristis and Turdoides striatus were occurred in all four sites, while Amaurornis phoenicurus, Himantopus himantopus present in site 2; Dinopium benghalense, Megalaima haemacephala, Upupa epops, Merops philippinus, Centropus sinensis, Athene brama were present in site 3 (forest area); Acridotheres ginginianus and Hirundo smithii bird species were only visitor of site 4 . Most of the bird species were native of our sites such as; Vanellus indicus, Bulbulcus ibis, Acridotheres tristis, Columba livia, Corvus splendens, and Dicrurus macrocercus and habitats of these birds were also there. These species of birds were frequently visiting all four sites but the three sites (site 1, site 3 and site 4) and these sites covered mostly bird habitat. In total species, a large number of species prefers visiting of these three sites. It was also found; the some species were not frequently visitor of our sites. Abundance of bird species were also recorded according to survey time and site.The results revealed that the highest number of species of bird (diversity) occurs in site 3 while site 2 showed less diversity (Figure - 3A). It was observed that the maximum bird's species were recorded during the season of spring and early summer, while comparatively less number of species was observed during the winter season. It was observed that the numbers of species was continuously increased from February to June according to survey time (Figure-3B) and the highest numbers of species were recorded in the month of June in all four sites (Figure - 3B). The present investigation also revealed that site 1 covered $26 \%$, site $2-16 \%$, site $3-30 \%$ and site 4 $28 \%$ families of total numbers of families in the all four sites (Figure- 4A). Of all total number of species $27 \%$ occurred in site $1,13 \%$ in site $2,31 \%$ in site 3 and $29 \%$ species were recorded in site 4 (Figure - 4B).
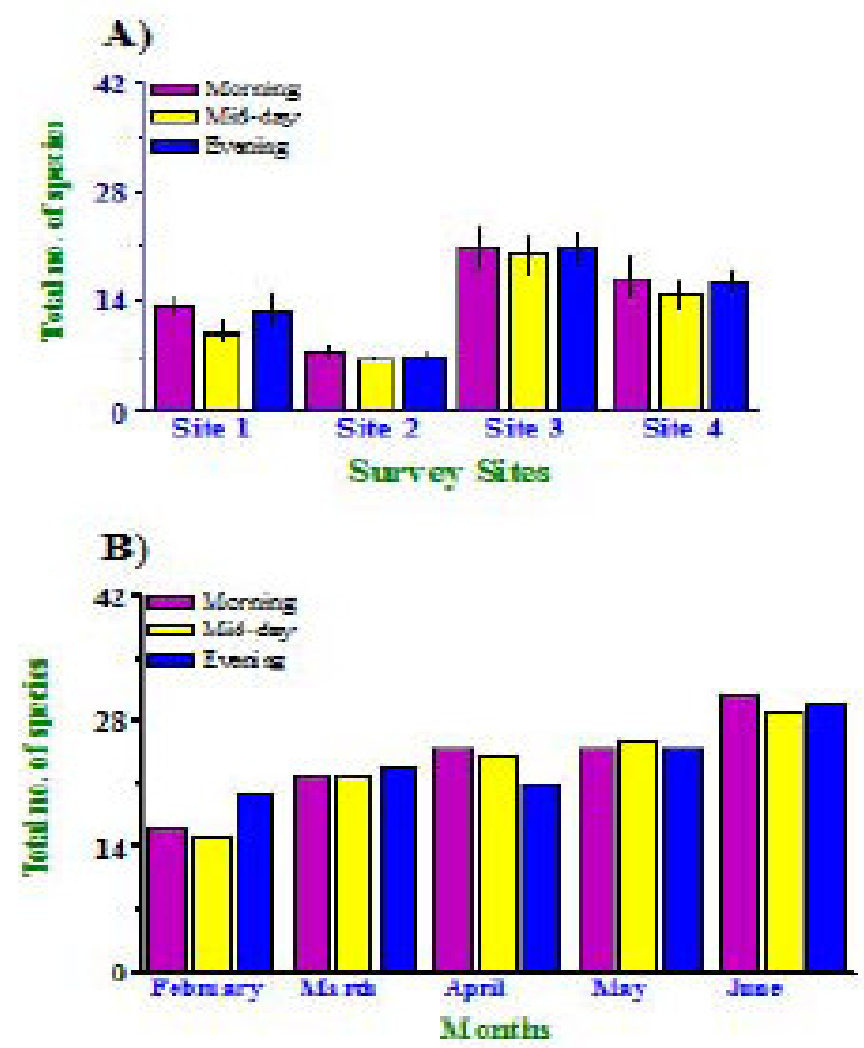

Fig. 3(A): The total number of species during morning, midday and evening time of survey period in all the sites (B) The total number of species during morning, midday and evening time of each month during the survey period.

\section{(A) Totalno. of family in sites}

\section{$\square$ Site $1 \backsim$ Site $2 \|$ Site $3 \approx$ Site 4}

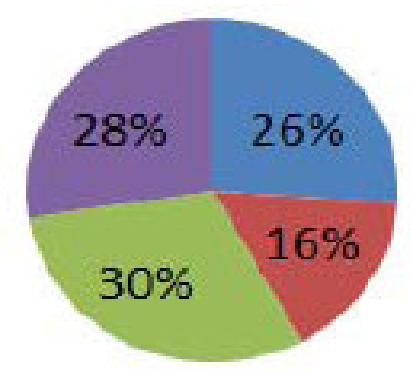

Fig. 4(A): The total number of families (\% value) of each site during the survey period 


\section{(B) Total no. of species in sites Site $1 \backsim$ Site 2 Site $3=$ Site 4}

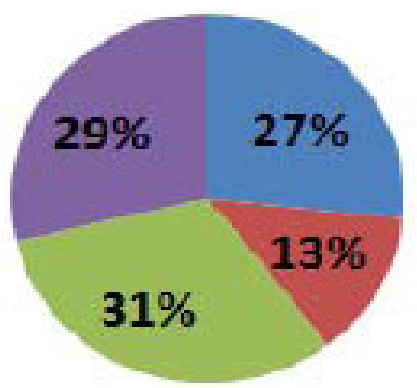

Fig. 4(B): The total number of species (\% value) of each site during the survey period

Among all groups of animals in the world, birds are more liked owing to their rich coloration, song, easy recognition and liveliness. Moreover birds are presented every-where from forest, grassland, wetland, to crop field and gardens. Our country is very rich in bird fauna. Of nearly 10,000 different kinds of in the world, 1300 species or about $15 \%$ of the world's birds are found in Indian subcontinent. The main reason of very rich bird diversity in India is the presence of varied habitats. Many types of grasslands, wetlands and forests support the survival of various species of birds and other animals. Of the total number of bird species, which are estimated around 8600 comprising of about 30,000 forms, Indian sub-continent with a vast diversity of climate and bio-physical features, possesses most probably the richest avifauna (Ali, 1964). Among the larger animals, 173 species of mammals and 78 species of birds (Islam and Rahmani, 2002) are considered.During the present investigation, 42 birds species belongs 36 genus, 26 families and 12 different orders were recorded from four sites. The site 3 showed high species diversity with 32 species while the site 4 showed 29 species, however 27 species were recorded from site 1 but the lowest birds diversity were recorded from site 2 (only 13 species). The family Columbidae, Sturnidae, Corvidae and Muscicapidae were dominant with highest species. During the survey it was also observed that the members of Corvidae family like Corvus splendens are considered the most intelligent of bird species. When they are catching food they appear to be sensitive to note who is watching them hide the food. Different species of birds have different social habitats. Some species of bird's lives in flocks while other loners and live in small family or groups. Pavo cristatus, Columba livia, Corvus splendens and Turdoides striatus were those species lived in their flocks. They perched with their flocks. The large grouping of birds was recorded in the species of Corvus splendens. The member of Halcyonidae family (Halcyon smyrnensis) and the member of family Dicruridae (Dicrurus macrocercus) also perched lonely.The investigation also suggested that most of the species spend their time in mixed habitat. They usually perched on a tree or some of them climbing on a tree or on a ground (Bubulcus ibis). Many birds follow strict time schedules in their activities. These are often depending upon environmental cues. Birds are also sensitive to day length and their awareness is especially important as cues for migration and seasonal behavior. The number of avian species in India is 1288 , which belong to 89 families and 17 orders. Due to excessive hunting, and destruction of natural habitats of birds, the species diversity decline drastically. Many species become extinct and most species are fighting for their existence.

\section{Conclusion}

A total of 42 species, belonging to 12 orders, 26 families and 36 genera, were recorded from Chaudhary Charan Singh University Campus, Meerut, (UP). The most of the bird's species were frequently visitor and also the most of the species used more than one habitat and the highest number of species $38(90.47 \%)$, was observed on the trees, whereas the lowest number of species $4(9.53 \%)$, was found around the ponds. Mostly the birds prefer mixed habitat and also their presence depends upon food availability. So, the environmental factor such as temperature and other appropriate conditions (i.e. availability of food and competition) play an important role in selection of habitat for a particular species. A number of environmental and man-made factors appeared to be responsible for declining population and species diversity of the birds in the study area. However, more systemic studies are needed to make the better conclusion of avifauna as well as biodiversity studies. 


\section{Acknowledgement}

Generous financial support through research grant (SR/SO/AS/36/2006 dated 18.10.2007) to SKB from the Department of Science and Technology, New Delhi is gratefully acknowledged. We have also the permission from the Chief Wildlife Warden, Forest department, Lucknow to work on the photoperiodic and spectral effects in small birds.

\section{References}

Ali, S. 1964. The best book of Indian birds, Bombay Natural History Society, Bombay, India.

Ali, S. and Ripley, S.D. (ed.) 1987. Handbook of Birds of India and Pakistan, $2^{\text {nd }}$ ed. Oxford University Press, New Delhi, India

Ali, S. and Ripley, S.D. 1989. A pictorial guide to the birds of the Indian subcontinent, $2^{\text {nd }}$ ed. Bombay Natural History Society, Mumbai, India.

Bird Life International. 2001. Threatened Birds of Asia, The BirdLife International Red Data Book. Part A. Collar, N. J., Andreev, A. V., Chan, S., Crosby, M. J., Subramanya, S. \& Tobias, J. A. (eds.) Cambridge, UK. (1): 1-1516.

Brush, H.A. and Clark, G. Jr. 1983. Prospectives in Ornithology, Cambridge University Press. Cambridge, London, New York, New Rochelle Melbourne, Sydney: $35-43$.

Grimmett, R., Inskipp, C. and Inskipp, T. 1998. Birds of the Indian Subcontinent, $1^{\text {st }}$ ed. Christopher Helm, A. \& Black C., London.
Grimmet, R., Inskipp, C. and Inskipp, T. 1999. A pocket guide to the birds of the Indian Subcontinent. Oxford University Press, New Delhi, India.

Grimmett, R. and Inskipp, T. 2003. Birds of Northern Indian, Oxford University Press, New Delhi, India.

Islam, M.Z. and Rahmani, A.R. 2002. Threatened birds of India, Buceros Vol. 7 (1\&2) Compiled from Threatened Birds of Asia, BirdLife International, Red Data Book (2001), Cambridge, UK: BirdLife International.

Jansen, A. and Robertson, A. I. 2001. Riparian bird communities in relation to land management practices in floodplain woodlands of south-eastern Australia. Biological Conservation, 100: 173-185.

Kumar, A., Walker, S. and Molur, S. 2000. Prioritisation of Endangered Species, Setting Biodiversity Conservation Priorities for India. Singh, S., Sastry, A. R. K., Mehta, R. \& Uppal V. New Delhi, WWF- India. 2: 341-425.

Rahmani, A.R., Narayan, G., Rosalind, L. and Sankaran, R. 1990. The status of the Bengal Floricanin India. In: Status and Ecology of Bengal and Lesser Florican with reports on Jerdon's Courser and Mountain Quail. Final Report, Bombay Natural History Society, Mumbai: 55-78.

Steresemann, E. (Ed.-Cottrell, W.G.) 1975. Ornithology: From Aristotle to the Present Haward University Press Cambridge, MA: 365-396.

Uliczka, H. and Angelstam, P. 2000. Assessing conservation values of forest stands based on specialised lichens and birds. Biological Conservation, 95: 343-351.

Woodcock, M. 1980. Collins Hand guide to the Birds of Indian sub-continent. $2^{\text {nd }}$ ed. Collins, London: 176. 